\title{
THE LIPIDS OF THE BLOOD PLASMA IN EPILEPSY
}

\section{Variations of Lipids in Relation to Occurrence of Seizures ${ }^{1,2}$}

BY IRVINE MCQUARRIE, CLARA HUSTED AND W. R. BLOOR

(From the Departments of Biochemistry and Pediatrics, University of Rochester, Rochester, New York, and the Department of Pediatrics, University of Minnesota, Minneapolis)

(Received for publication October 7, 1932)

From the data presented in the preceding paper (1) it is impossible to ascertain whether there is any direct relationship between the concentration of the plasma lipids and the occurrence of convulsive seizures. When Robinson, Brain and Kay (2) determined the cholesterol of the blood at regular intervals throughout the day in 11 cases of severe epilepsy, they found this constituent to fall to subnormal levels in the majority of their cases just prior to the onset of seizures. With the hope of obtaining further information regarding the nature of any relationship that might exist between the two phenomena, we have made repeated determinations of the plasma lecithin and total fatty acids as well as cholesterol in a series of severely epileptic children. Diet and length of time between samples have been the only important variables. The procedures used for obtaining and analyzing the blood samples were the same as those described in the previous paper. The special conditions of the various experiments will be described as the results are presented.

\section{RESULTS}

The results to be presented fall into two somewhat different categories. The first consists of data obtained on eight comparatively severe epileptics in the course of a single day during which serial blood samples were taken at more or less regular intervals. The second comprises a series of more elaborate individual studies on three severely epileptic girls, who were subjected to a variety of test regimens over periods of much greater length.

The data on the short period serial observations are recorded in Tables 1 and 2. Both tables show the variations throughout the day in total fatty acid, lecithin and cholesterol and in the lecithin-cholesterol ratio in relation to the occurrence of seizures. The results on cases

${ }^{1}$ Presented at the annual meeting of the American Pediatric Society at Edgewater Park, Mississippi, April 17, 1931.

2 Aided by grants from an anonymous donor and from the Ella Sachs Plotz Foundation. 
having seizures during the forepart of the day are grouped together in Table 1. The data on two patients having convulsions in the afternoon as well as in the forenoon and those on one patient having none throughout

TABLE 1

Variations in plasma lipids during the day in relation to convulsions

\begin{tabular}{|c|c|c|c|c|c|c|c|}
\hline Patient & $\begin{array}{l}\text { Time of } \\
\text { sample }\end{array}$ & & $\begin{array}{l}\text { Time of } \\
\text { seizures }\end{array}$ & $\begin{array}{c}\text { Total } \\
\text { fatty acid }\end{array}$ & Lecithin & $\begin{array}{c}\text { Choles- } \\
\text { terol }\end{array}$ & $\frac{\text { Lecithin }}{\text { Cholesterol }}$ \\
\hline $\begin{array}{l}\text { M. B. } \\
\text { (Seizures } \\
\text { early in } \\
\text { day) }\end{array}$ & $\begin{array}{r}9: 45 \\
11: 40 \\
1: 40 \\
1: 50 \\
3: 45 \\
5: 45 \\
7: 45\end{array}$ & $\begin{array}{l}\text { A.M. } \\
\text { P.M. }\end{array}$ & $\begin{array}{r}8: 00 \\
11: 32 \\
1: 45\end{array}$ & $\begin{array}{c}\text { mgm. per } \\
100 \text { cc. } \\
293 \\
311 \\
302 \\
334 \\
280 \\
340 \\
385\end{array}$ & $\begin{array}{c}\text { mgm. per } \\
100 \text { cc. } \\
197 \\
197 \\
186 \\
197 \\
75 \\
153 \\
200\end{array}$ & $\begin{array}{c}\text { mgm. per } \\
100 \text { cc. } \\
169 \\
178 \\
182 \\
167 \\
146 \\
183 \\
189\end{array}$ & 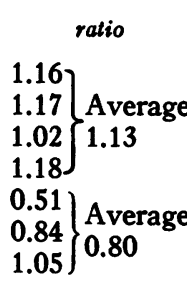 \\
\hline $\begin{array}{l}\text { S. W. } \\
\text { (Seizures } \\
\text { in fore- } \\
\text { noon) }\end{array}$ & $\begin{array}{r}9: 35 \\
10: 03 \\
11: 25 \\
1: 25 \\
3: 30 \\
5: 35 \\
7: 25\end{array}$ & $\left.\right|_{\text {P.M. }} ^{\text {A.M. }}$ & $\begin{array}{r}9: 43 \\
11: 23\end{array}$ & $\begin{array}{l}374 \\
319 \\
321 \\
339 \\
319 \\
328 \\
318\end{array}$ & $\begin{array}{l}197 \\
182 \\
178 \\
153 \\
153 \\
131 \\
130\end{array}$ & $\begin{array}{l}176 \\
173 \\
165 \\
169 \\
173 \\
180 \\
173\end{array}$ & $\begin{array}{l}\left.\begin{array}{l}1.12 \\
1.05 \\
1.08\end{array}\right\} 1.08 \\
0.98 \\
\left.\begin{array}{l}0.89 \\
0.73 \\
0.76\end{array}\right\} 0.84\end{array}$ \\
\hline $\begin{array}{l}\text { M. O. } \\
\text { (Seizures } \\
\text { early in } \\
\text { day) }\end{array}$ & $\begin{array}{r}10: 05 \\
12: 05 \\
2: 05 \\
2: 55 \\
4: 55 \\
6: 55 \\
8: 55\end{array}$ & $\begin{array}{l}\text { A.M. } \\
\text { P.M. } \\
1\end{array}$ & $\begin{array}{r}7: 40 \\
11: 58 \\
12: 50\end{array}$ & $\begin{array}{l}262 \\
288 \\
264 \\
256 \\
267 \\
259 \\
257\end{array}$ & $\begin{array}{l}164 \\
184 \\
145 \\
160 \\
147 \\
135 \\
111\end{array}$ & $\begin{array}{l}133 \\
144 \\
136 \\
142 \\
142 \\
141 \\
147\end{array}$ & $\begin{array}{l}\left.\begin{array}{l}1.23 \\
1.28 \\
1.07 \\
1.12\end{array}\right\} 1.17 \\
\left.\begin{array}{l}\text { Average } \\
0.03 \\
0.96 \\
0.75\end{array}\right\} 0.91\end{array}$ \\
\hline $\begin{array}{l}\text { M. B. } \\
\text { (Early } \\
\text { morning } \\
\text { seizure) }\end{array}$ & $\begin{array}{r}10: 17 \\
12: 17 \\
2: 17 \\
4: 20 \\
6: 20 \\
8: 20\end{array}$ & $\begin{array}{l}\text { A.M. } \\
\text { P.M. }\end{array}$ & $5: 20$ & $\begin{array}{l}309 \\
303 \\
254 \\
280 \\
267 \\
271\end{array}$ & $\begin{array}{r}175 \\
164 \\
82 \\
97 \\
71 \\
106\end{array}$ & $\begin{array}{l}155 \\
146 \\
120 \\
132 \\
129 \\
133\end{array}$ & 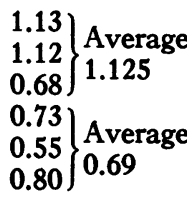 \\
\hline $\begin{array}{c}\text { M. G. } \\
\text { (Frequent } \\
\text { petit mal) }\end{array}$ & $\begin{array}{r}9: 49 \\
10: 50 \\
1: 00 \\
3: 00 \\
5: 00 \\
7: 00 \\
9: 00\end{array}$ & $\begin{array}{l}\text { A.M. } \\
\text { P.M. } \\
!^{\text {P. }}\end{array}$ & $\begin{array}{l}\text { Petit mal } \\
\text { less fre- } \\
\text { quent in } \\
\text { evening }\end{array}$ & $\begin{array}{l}319 \\
328 \\
269 \\
313 \\
288 \\
285 \\
283\end{array}$ & $\begin{array}{r}160 \\
160 \\
157 \\
171 \\
95 \\
134 \\
145\end{array}$ & $\begin{array}{l}159 \\
151 \\
163 \\
165 \\
153 \\
163 \\
158\end{array}$ & $\begin{array}{l}\left.\left.\begin{array}{l}1.01 \\
1.06 \\
0.95 \\
1.03\end{array}\right\} \begin{array}{l}\text { Average } \\
0.01 \\
0.82 \\
0.92\end{array}\right\} 0.84 \\
\text { Average }\end{array}$ \\
\hline
\end{tabular}

the period of observation are presented in Table 2. All of these subjects were kept in bed without food during the period of study.

Inspection of the figures presented reveals the fact that, with a few 
scattered exceptions, they are all within the range of normal. While it is true that patient A. C., who had no seizures throughout the day (Table 2), showed definitely higher cholesterol values than any of the other subjects

TABLE 2

Variations in plasma lipids during the day in relation to convulsions

\begin{tabular}{|c|c|c|c|c|c|c|c|c|}
\hline Patient & $\begin{array}{l}\text { Time of } \\
\text { sample }\end{array}$ & & $\begin{array}{l}\text { Time of } \\
\text { seizures }\end{array}$ & $\begin{array}{l}\text { Total } \\
\text { fatty acid }\end{array}$ & Lecithin & $\begin{array}{c}\text { Choles- } \\
\text { terol }\end{array}$ & \multicolumn{2}{|c|}{$\frac{\text { Lecithin }}{\text { Cholesterol }}$} \\
\hline $\begin{array}{c}\text { A. C. } \\
\text { (No seizures } \\
\text { during day) }\end{array}$ & $\begin{array}{r}10: 14 \\
12: 13 \\
2: 14 \\
4: 15 \\
7: 10\end{array}$ & $\begin{array}{l}\text { A.M. } \\
\text { P.M. }\end{array}$ & $\begin{array}{l}\text { None } \\
\text { None }\end{array}$ & $\begin{array}{c}\text { mgm. per } \\
100 \text { cc. } \\
361 \\
376 \\
297 \\
360 \\
330\end{array}$ & $\begin{array}{c}\text { mgm. per } \\
100 \text { cc. } \\
192 \\
206 \\
173 \\
155 \\
201\end{array}$ & $\begin{array}{c}\text { mgm. per } \\
100 \text { cc. } \\
198 \\
231 \\
195 \\
192 \\
213\end{array}$ & $\left.\begin{array}{l}0.97 \\
0.84 \\
0.89 \\
0.81 \\
0.87\end{array}\right\}$ & $\begin{array}{l}\text { ratio } \\
\text { Average } \\
0.87\end{array}$ \\
\hline $\begin{array}{c}\text { E. V. } \\
\text { (Seizures } \\
\text { in A.M. } \\
\text { and P.M.) }\end{array}$ & $\begin{array}{r}10: 07 \\
10: 44 \\
11: 35 \\
1: 35 \\
3: 35 \\
5: 55 \\
7: 55\end{array}$ & $\begin{array}{l}\text { A.M. } \\
\text { P.M. }\end{array}$ & $\begin{array}{r}10: 16 \\
2: 33\end{array}$ & $\begin{array}{l}310 \\
551 \\
527 \\
284 \\
291 \\
249 \\
258\end{array}$ & $\begin{array}{l}137 \\
110 \\
142 \\
145 \\
153 \\
145 \\
105\end{array}$ & $\begin{array}{l}111 \\
106 \\
117 \\
121 \\
115 \\
132 \\
123\end{array}$ & $\left.\begin{array}{l}1.23 \\
1.04 \\
1.42 \\
1.20 \\
1.33 \\
1.10 \\
0.85\end{array}\right\}$ & $\begin{array}{l}\text { Average } \\
1.16 \\
\text { Average } \\
1.12\end{array}$ \\
\hline $\begin{array}{l}\text { L. T. } \\
\text { (Seizures } \\
\text { in A.M. } \\
\text { and P.M.) }\end{array}$ & $\begin{array}{l}9: 51 \\
\\
1: 35 \\
3: 15 \\
3: 50 \\
5: 50 \\
7: 50\end{array}$ & $\begin{array}{l}\text { A.M. } \\
\text { P.M. }\end{array}$ & $\begin{array}{r}5: 07 \\
12: 10 \\
1: 30 \\
3: 13 \\
\\
5: 00\end{array}$ & $\begin{array}{l}311 \\
\\
371 \\
327 \\
287 \\
294 \\
314\end{array}$ & $\begin{array}{l}147 \\
\\
167 \\
153 \\
164 \\
126 \\
153\end{array}$ & $\begin{array}{l}130 \\
\\
129 \\
141 \\
136 \\
129 \\
128\end{array}$ & $\left.\begin{array}{l}1.13 \\
1.29 \\
1.08 \\
1.20 \\
0.98 \\
1.19\end{array}\right\}$ & $\begin{array}{l}\text { Average } \\
1.16 \\
\text { Average } \\
1.12\end{array}$ \\
\hline
\end{tabular}

in this group, there was no consistent relationship between the absolute level of any single lipid fraction and the occurrence of convulsions in those patients who did experience them. The few subnormal cholesterol values recorded did not occur near the time of seizures excepting in one instance.

One feature of the data, which may or may not be of significance, became apparent when the relative changes in the lecithin and cholesterol were studied. That is, the average lecithin-cholesterol ratio was higher during that part of the day when seizures occurred than during periods when they did not occur. While this difference was not great, it occurred consistently in the five cases having seizures chiefly in the forenoon. Alterations in the ratio were not regularly due to a decrease in one constituent or to an increase in another. Both might be increased or decreased at the same time but to different degrees, or one might remain stationary while the other rose or fell, or finally one might be elevated and the other simultaneously depressed. The fact, that there was but little difference between the values of the ratio for the forenoon and those for the after- 
noon in the case having no seizures at all and in the two cases having seizures during both periods (Table 2), suggests that the association of seizures with the higher ratios in the other cases may have some significance.

TABLE 3

Relation of lecithin-cholesterol ratio to time of conoulsion (ketogenic diet-water ad lib.)

\begin{tabular}{|c|c|c|c|c|c|}
\hline Time of blood sample & $\begin{array}{c}\text { Number } \\
\text { of } \\
\text { analyses } \\
\text { averaged }\end{array}$ & $\begin{array}{l}\text { Total } \\
\text { fatty } \\
\text { acid }\end{array}$ & Lecithin & $\begin{array}{c}\text { Choles- } \\
\text { terol }\end{array}$ & $\frac{\text { Lecithin }}{\text { Cholesterol }}$ \\
\hline & & $\begin{array}{c}\text { mgm. per } \\
100 \text { cc. }\end{array}$ & $\begin{array}{c}\text { mgm. per } \\
100 \mathrm{cc} .\end{array}$ & $\begin{array}{l}\text { mgm. per } \\
100 \text { cc. }\end{array}$ & ratio \\
\hline Within 1 hour of seizure. . . . . . . . & 2 & 1019 & 255 & 183 & 1.39 \\
\hline Between 1 and 2 hours from seizure... & 4 & 761 & 246 & 190 & 1.30 \\
\hline Between 2 and 12 hours from seizure. . & 3 & 633 & 247 & 205 & 1.20 \\
\hline More than 12 hours from seizure. ....... & 9 & 459 & 227 & 206 & 1.10 \\
\hline${ }^{*}$ Two months from seizure.$\ldots \ldots \ldots \ldots \ldots$ & 1 & 376 & 210 & 192 & 1.09 \\
\hline
\end{tabular}

* Water intake limited to 30 grams per $\mathrm{kgm}$. in 24 hours.

The data summarized in Table 3 were obtained under somewhat different conditions. The patient concerned was a severely epileptic girl ten years of age, who responded fairly well but not entirely satisfactorily to the ketogenic dietary regimen. The determinations tabulated were made over a period of several months during which the nursing supervision was quite adequate for accurate recording of all seizures. It is obvious that all of the lipid fractions were either slightly elevated or were near the upper limits of normal at all times and that the values for the lecithin-cholesterol ratio tended to be above those found in the cases just presented. Here again the ratio tended to be highest in those plasma samples obtained nearest to the time of seizures and lowest in those most remote in time from seizures. This was apparently true whether or not the sampling was carried out before or after a seizure. Although the patient's clinical response to the ketogenic diet was much more satisfactory when water restriction was employed in conjunction with it, this modification in the therapeutic regimen had but little influence on the plasma lipids.

The data summarized in Tables 4 and 5 were obtained in connection with a 41-day study reported elsewhere on the relationship of alterations in the acid-base equilibrium to the occurrence of convulsions in the case of a severely epileptic girl aged 13 years (3). As indicated in Table 4 various dietary regimens were successively employed to determine their effectiveness in preventing seizures. The first three plasma samples were obtained at intervals of several weeks, while the patient was on an ordinary mixed diet and before the controlled experimental study was begun. 
TABLE 4

Correlation between changes in plasma lipids and occurrence of convulsions on various dietary regimens (severe epilepsy)

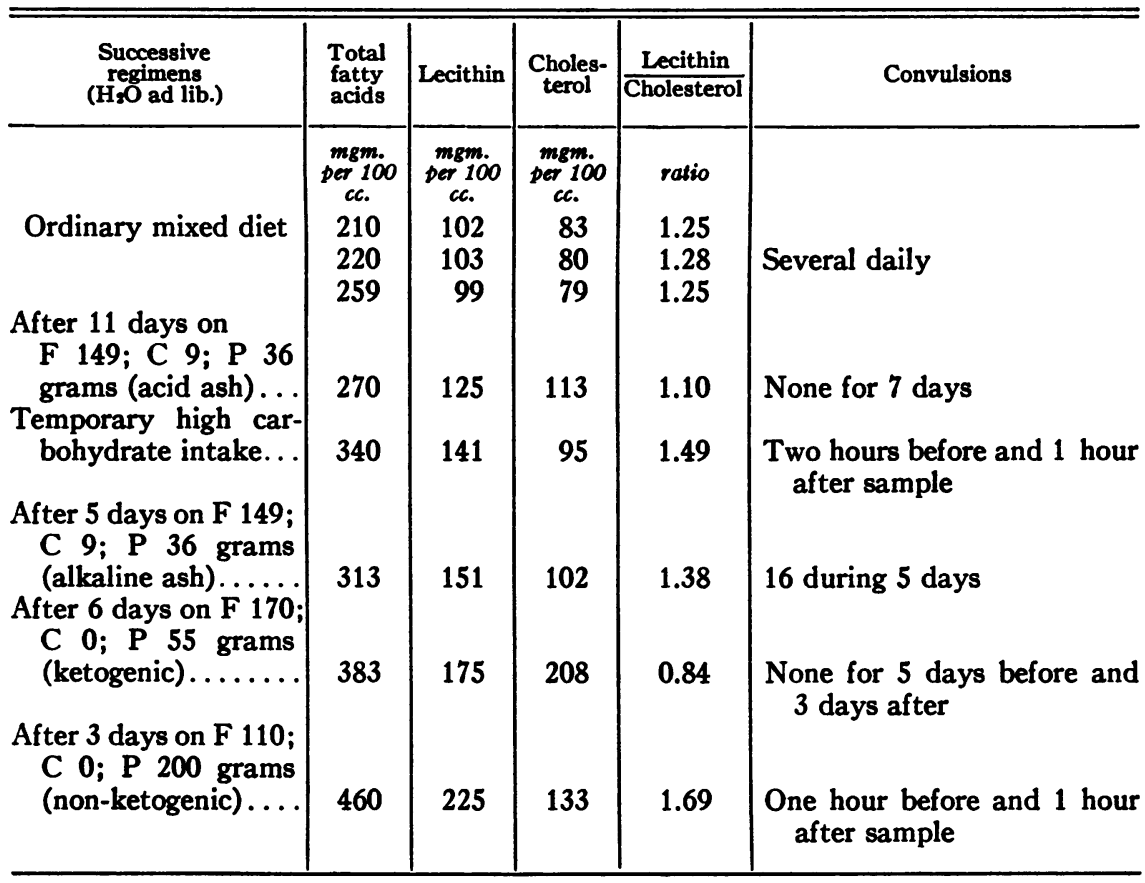

TABLE 5

Relation of lecithin-cholesterol ratio to time of convulsion (Diet: C 0; P 200; F 110 grams)

\begin{tabular}{|c|c|c|c|c|c|}
\hline Time of blood sample & $\begin{array}{c}\text { Number of } \\
\text { analyses } \\
\text { averaged }\end{array}$ & $\begin{array}{l}\text { Total } \\
\text { fatty } \\
\text { acid }\end{array}$ & Lecithin & Cholesterol & $\frac{\text { Lecithin }}{\text { Cholesterol }}$ \\
\hline & & $\begin{array}{l}\text { mgm. per } \\
100 \text { ce. }\end{array}$ & $\begin{array}{l}\text { mgm. per } \\
100 \text { cc. }\end{array}$ & $\begin{array}{l}\text { mgm. per } \\
100 \text { cc. }\end{array}$ & ratio \\
\hline $\begin{array}{l}\text { Within } 1 \text { hour of seizures..... } \\
\text { Between } 2 \text { and } 12 \text { hours from }\end{array}$ & 2 & 384 & 260 & 124 & 2.09 \\
\hline $\begin{array}{r}\text { seizures. } \ldots \ldots \ldots \ldots \ldots \\
\text { Between } 12 \text { and } 24 \text { hours from }\end{array}$ & 3 & 363 & 228 & 116 & 1.96 \\
\hline $\begin{array}{l}\text { seizures. . . . . . . . . . . . . . . . } \\
35 \text { hours from seizures (fasting }\end{array}$ & 2 & 347 & 213 & 125 & 1.70 \\
\hline 48 hours) $\ldots \ldots \ldots \ldots \ldots \ldots$ & 1 & 330 & 175 & 121 & 1.44 \\
\hline
\end{tabular}

All of the blood lipids had been found to be consistently low in this patient at various times over a period of two years before the present study was made. It may be seen from the table that the cholesterol remained slightly subnormal or barely within the lower range of normal in all but one of the subperiods of the experiment, whereas the lecithin and total fatty acid values fluctuated from below normal to a point $\mathbf{5 0}$ 
per cent above their average normal levels. Although the first three plasma analyses recorded in Table 4 show subnormal lipid values, the lecithin-cholesterol ratios are well above unity. These values probably represent the relationships ordinarily occurring in this patient, when she was not under special dietary control. Data from a large group of patients of this type would undoubtedly support the claim of Robinson, Brain and Kay (2) and others that hypocholesterinemia is characteristic of the epileptic state.

The effects of various dietary regimens on the occurrence of seizures and on the different lipid fractions of the blood are clearly brought out in these results. It is evident that an increase in lecithin was more consistently associated with seizures than a decrease in cholesterol. It is difficult to determine with certainty whether these changes preceded or followed the convulsions because most of the samples were obtained between two seizures. An increase in the plasma cholesterol, such as that which occurred during the fifth subperiod, without an equivalent rise in the lecithin would appear to be indicative of a favorable change in the metabolism of the brain cells, because it coincided in this instance with a complete cessation of convulsions and marked improvement in the patient's mental reactions.

That the ketogenic effect of the diet was essential for this change is suggested by the marked alteration in the various values which followed substitution of another carbohydrate-free diet containing protein and fat in non-ketogenic proportions, as shown in subperiod 6. Following this change in regimen, which resulted in recurrence of seizures in great numbers, the values for lecithin were markedly increased while those for cholesterol were actually decreased. Table 5 summarizes the data obtained on this patient over a span of eight days while she remained on the high-protein, carbohydrate-free diet shown for subperiod 6 . It is seen that the $\frac{\text { lecithin }}{\text { cholesterol }}$ values were significantly higher during this than any other subperiod of the study.

A third epileptic girl was studied over a period of two months, the time being divided into subperiods in which various dietary regimens were tested as to their efficiency in preventing epileptic seizures. The effect upon the blood lipid levels was determined at the end of each subperiod. Of the various regimens employed, fasting and a strongly ketogenic diet (protein 25 grams, fat 122 grams, and carbohydrate 5 grams) were the only ones effective in preventing seizures, so long as the water intake was unrestricted. The levels of the various plasma lipids were unusually high in this patient throughout the entire period of observation. However, no determinations were made until after she had been taking a ketogenic diet for ten days, at the end of which time the plasma lipid values were approximately double the normal (see Table 6). 
TABLE 6

Effect of ketogenic diet on occurrence of seizures and on plasma lipids. Compatibility of high lipid levels with occurrence of seizures

\begin{tabular}{|c|c|c|c|c|}
\hline Conditions & $\begin{array}{l}\text { Total fatty } \\
\text { acid }\end{array}$ & Lecithin & Cholesterol & $\frac{\text { Lecithin }}{\text { Cholesterol }}$ \\
\hline At end of 10 days on ketogenic diet (no & $\begin{array}{l}\text { mgm. per } \\
100 \text { ce. }\end{array}$ & $\begin{array}{l}\text { mgm. per } \\
100 \text { cc. }\end{array}$ & $\begin{array}{l}\text { mgm. per } \\
100 \mathrm{cc.}\end{array}$ & ratio \\
\hline $\begin{array}{l}\text { seizures) } \ldots \ldots \ldots \ldots \ldots \ldots \ldots \ldots \ldots \\
\text { During status epilepticus following }\end{array}$ & 527 & 269 & 347 & 0.75 \\
\hline 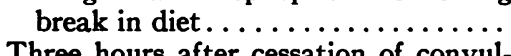 & 358 & 270 & 298 & 0.90 \\
\hline 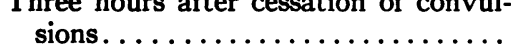 & 285 & 276 & 308 & 0.89 \\
\hline
\end{tabular}

The patient was discharged from the hospital shortly after the first set of figures shown in the table were obtained. One week later, however, she was readmitted in status epilepticus following a break in diet. Figures for the blood lipids determined at the height of the attack and again three hours after the cessation of seizures are also recorded in Table 6. A small amount of ether was administered by face mask five minutes before the first blood sample was drawn. Whether this procedure had any effect on the plasma lipid values is uncertain. After the patient had fasted for four days with no further occurrence of seizures, the levels of all the lipids had risen still higher. It will be noted that the lecithin-cholesterol ratio was very much lower in this than in the two previous cases.

TABLE 7

Effects of prolonged use of carbohydrate-free diets with varying proportions of protein and fat upon occurrence of seizures and upon plasma lipids. Seizures during nonketogenic periods in spite of elevated lipids

\begin{tabular}{|c|c|c|c|c|c|}
\hline & $\begin{array}{c}\text { Diet } \\
\text { (8-day periods) }\end{array}$ & Total fatty acid & Lecithin & Cholesterol & $\frac{\text { Lecithin }}{\text { Cholesterol }}$ \\
\hline 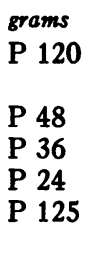 & $\begin{array}{l}\text { grams } \\
\text { F } 60 \text { (non-keto- } \\
\text { F } 92 \text { (kenic) } \\
\text { F } 98 \text { (ketogenic) } \\
\text { F } 102 \text { (ketogenic) } \\
\text { F } 58 \text { (non-keto- }\end{array}$ & $\begin{array}{c}\text { mgm. per } 100 \text { cc. } \\
340 \\
801 \\
767 \\
1045 \\
1463\end{array}$ & $\begin{array}{c}\text { mgm. per } 100 \text { cc. } \\
401 \\
400 \\
371 \\
433 \\
456\end{array}$ & $\begin{array}{c}\text { mgm. per } 100 \text { cc. } \\
489 \\
505 \\
505 \\
555 \\
513\end{array}$ & $\begin{array}{l}\text { ratio } \\
0.82 \\
0.79 \\
0.73 \\
0.78 \\
0.88\end{array}$ \\
\hline
\end{tabular}

Following the four-day fasting period, an experiment of forty days duration was carried out to determine the effects of various carbohydratefree diets. The period was divided into five almost equal subperiods in which different levels of protein intake were maintained. The diet remained isocaloric throughout, a sufficient number of calories in the form of fat being added to replace the protein withdrawn with each 
change in diet. The use of these carbohydrate-free diets produced a still further rise in the levels of the different lipids (see Table 7). In spite of the high concentrations of these substances in the plasma, however, the patient continued to have occasional seizures. These were noticeably more frequent during subperiods when the diet contained fat and protein in non-ketogenic proportions than during the other subperiods. It would appear from the high values shown in this table that there is no fixed threshold for any one of the plasma lipids above which seizures can be predicted not to occur. These data demonstrate also that the relationship between the blood lipid values and the occurrence of convulsions is not a simple one.

This same patient was readmitted for observation three months after the last analyses recorded in Table 7 were made, the intervening time having been spent at home on a mildly ketogenic diet with moderate restriction of the water intake, a regimen which apparently reduced the number of seizures very materially. Although definitely decreased below the previous high level, the blood lipids were still found to be approximately 50 per cent above normal. During the next two weeks the effects of changing abruptly to an ordinary house diet (i.e. one relatively high in carbohydrate) were studied. At the end of two weeks on the latter regimen carbohydrate alone was given for 24 hours. The influence of these changes in diet upon the plasma lipids is shown in Table 8. It will be observed that, in the shifts which took place in the

TABLE 8

Effect of change in diet on plasma lipids. Occurrence of convulsions in spite of high level

\begin{tabular}{|c|c|c|c|c|}
\hline Successive regimens & $\begin{array}{c}\text { Total } \\
\text { fatty acid }\end{array}$ & Lecithin & Cholesterol & $\frac{\text { Lecithin }}{\text { Cholesterol }}$ \\
\hline & $\begin{array}{l}\text { mgm. per } \\
100 \text { cc. }\end{array}$ & $\begin{array}{l}\text { mgm. per } \\
100 \mathrm{cc.}\end{array}$ & $\begin{array}{c}\text { mgm. per } \\
100 \text { cc. }\end{array}$ & \\
\hline 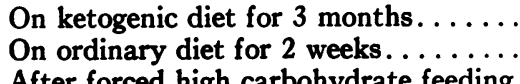 & $\begin{array}{l}434 \\
509\end{array}$ & $\begin{array}{l}284 \\
285\end{array}$ & $\begin{array}{l}323 \\
291\end{array}$ & $\begin{array}{l}0.88 \\
0.98\end{array}$ \\
\hline 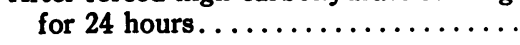 & 358 & 250 & 216 & 1.15 \\
\hline
\end{tabular}

plasma lipids, there were greater decreases in the total fatty acid and cholesterol values than in the lecithin. The observed diminution in the amounts of the various lipids is consistent with the abrupt clearing up of any simple lipemia, that is, the decrease is seen first in fatty acid, next in the cholesterol, and lastly in the lecithin. Seizures were definitely more frequent after the institution of the high carbohydrate diet. These data again demonstrate that there is no constant threshold value for any one of the plasma lipids, nor for the lecithin-cholesterol ratio, below which seizures can be predicted to occur, and above which they can be predicted not to occur. 


\section{DISCUSSION}

The foregoing results and those described in the preceding paper support the opinion that there is some obscure abnormality in the lipid economy of the body in epilepsy, which may be reflected in the blood as disturbances in the balance between the cholesterol and phospholipid fractions. While definitely decreased in exceptional cases, plasma cholesterol was found to be essentially normal in the great majority of juvenile epileptics examined. The plasma lecithin, on the other hand, tended to increase absolutely as well as relatively in many instances at or near the time of seizures.

The apparent contradiction between the latter observation, detailed in the present paper, and the finding of subnormal plasma lecithin in the large group of milder institutional patients, as recorded in the preceding communication, may find partial explanation in the difference in frequency of convulsions in the two groups. Difference in diet, of course, can not be said with certainty not to be a contributing factor, since the "mixed" diet of the institution may be very different from the ordinary, non-institutional "mixed" diet. Inspection of the data presented leaves one with the impression, however, that hypolecithinemia of varying degrees may characterize the epileptic subject during the quiescent phase of the disease, but that there is likely to be an increase in plasma lecithin during the active convulsive phase.

A satisfactory interpretation of our data in relation to the mechanism of seizures is impossible until further information has been obtained. However, if the blood changes may be regarded as reflecting alterations in the fixed tissues of the central nervous system, or if the concentrations of lecithin and cholesterol in the plasma influence their concentrations in the cells of the brain, the foregoing results might reasonably be interpreted as favoring the view that some relationship exists between a specific type of disturbance in brain cell physiology and the occurrence of convulsive seizures. That variations in the proportions of lecithin and cholesterol in the blood (or in the cells of the central nervous system) may influence irritability is indicated by various facts. For instance, when cholesterol is injected intravenously, in normal animals, it produces profound narcosis. Lecithin appears to have an opposite effect for, when it is administered parenterally in conjunction with a narcotic, it shortens the period of narcosis. On the other hand, when given with a convulsant drug, such as strychnine, lecithin diminishes the convulsive dose. As is well known, several of the current theories of narcosis and sedation take into account equilibria involving the various cell lipids, particularly in connection with the concept of cell membrane permeability (4).

Comparative analyses of the brain tissue of epileptic and non-epileptic subjects of similar ages for the various lipids might throw additional light on the subject. It may be significant in this connection that brain tissue 
normally contains more than twice the concentration of cholesterol during adult life that it contains during infancy (5), the period of life when susceptibility to convulsions from any cause is highest. Lecithin, on the other hand, is almost as great in amount in the brain of the child as in that of the adult (6). The interesting observation of Walker and Wheeler (7), that seizures were greatly reduced in number when severely epileptic patients were allowed to develop pellagra by the use of either ketogenic or non-ketogenic pellagra-producing diets, may ultimately find its explanation in the chemical changes in the nervous system which occur in the latter disease.

In the light of the possible relationship of increased plasma lecithin to the occurrence of seizures, it is of interest in passing to note the recent observation of Potick regarding the action of snake venom on plasma lipids (8). The author found that this poison, which has long been claimed to possess definite therapeutic value in epilepsy, lowers the plasma lecithin. We have had no experience in the therapeutic use of venoms but believe that the subject warrants further study.

The tentative conclusion suggested by the present study, namely, that a relative increase in plasma lecithin favors the occurrence of seizures while a relative increase in cholesterol tends to prevent them, is not out of harmony with recent observations on the relationship of epileptic seizures to the water balance of the body (9) (10). Degkwitz (11) found that the parenteral administration of cholesterol induced a negative water balance in normal rabbits, whereas lecithin caused water retention.

\section{SUMMARY}

1. Plasma lecithin, cholesterol and total fatty acids were determined repeatedly throughout the day in each of eight severely epileptic children. No constant relationship was found to exist between the absolute level of any one of these constituents and the occurrence of seizures. However, the lecithin-cholesterol ratios showed a tendency to be higher during the fore part of the day than during the late afternoon in patients having seizures in the first half of the day only. On the other hand, in two patients having seizures in the afternoon as well as in the forenoon and in one patient having none throughout the period of observation, the average values for the ratio were not significantly different for the two periods of the day.

2. The various lipid fractions were determined at different intervals in three other severely epileptic children under a variety of conditions. The two less severe patients developed marked hypercholesterinemia and hyperlecithinemia following the use of strongly ketogenic diets. While the frequency and the severity of seizures were definitely diminished in these subjects during their special dietary periods, convulsions occurred at times in spite of marked elevation of the plasma lipids. 
3. The most severely epileptic patient studied showed hypocholesterinemia consistently over a period of many months except for one short period, when the cholesterol rose to $208 \mathrm{mgm}$. per $100 \mathrm{cc}$. of blood following the use of a carbohydrate-free, ketogenic diet. The plasma lecithin, at times low, was strikingly more variable than the cholesterol. The patient showed a marked increase in lecithin without a significant change in the level of cholesterol at the time when seizures were most frequent.

4. While the absolute values for the individual lipid constituents of the plasma and those for the lecithin-cholesterol ratio differed greatly in the patients studied, the latter showed one tendency in common, namely, for the ratio of lecithin to cholesterol to be higher at or near the time of convulsions than at other times. The significance of this observation cannot be determined until further data have been obtained.

\section{BIBLIOGRAPHY}

1. McQuarrie, Irvine, Bloor, W. R., Husted, Clara, and Patterson, H. A., J. Clin. Invest., 1933, xii, 247. The Lipids of the Blood Plasma in Epilepsy. I. A Statistical Study of Single Determinations in 100 Epileptic and 32 "Normal" Subjects.

2. Robinson, S. H. G., Brain, W. R., and Kay, H. D., Lancet, 1927, ii, 325. The Association of Low Blood Cholesterol with the Occurrence of Fits in Epileptics.

3. McQuarrie, Irvine, and Keith, H. M., Am. J. Dis. Child., 1929, xxxvii, 261. Experimental Study of the Acid-Base Equilibrium in Children with Idiopathic Epilepsy.

4. (a) Overton, E. Studien über die Narkose, zugleich ein Beitrag zur allgemeinen Pharmakologie. Gustav Fischer, Jena 1901.

(b) Winterstein, H. Die Narkose in ihrer Bedeutung für die allgemeine Physiologie. Julius Springer, Berlin, 1926, 2nd ed.

(c) Lillie, R. S. Protoplasmic Action and Nervous Action. University of Chicago Press, Chicago, 1923.

5. Rosenheim, Quoted by Mathews, A. P. Physiological Chemistry. William Wood and Company, N. Y., 1930, 5th ed.

6. Koch, W., Ztschr. f. Physiol. Chemie, 1909, lxiii, 432. Die Bedeutung der Phosphatide (Lecithane) für die lebende zelle. II. Mitteilung.

7. Walker, N. P., and Wheeler, G. A., U. S. Public Health Reports, 1931, xlvi, 851. Influence on Epilepsy of a Diet Low in the Pellagra-Preventive Factor.

8. Potick, D., Compt. rend. Soc. de biol., 1930, cv, 307. Action des venins de Serpents sur les lipides du plasma sanguin.

9. Fay, Temple, Am. J. Psychiat., 1929, viii, 783. Some Factors in the "Mechanical Theory of Epilepsy" with Especial Reference to the Influence of Fluid, and Its Control, in the Treatment of Certain Cases.

10. McQuarrie, Irvine, Am. J. Dis. Child., 1929, xxxviii, 451. Epilepsy in Children. The Relationship of Water Balance to the Occurrence of Seizures.

11. Degkwitz, R., Klin. Wchnschr., 1930, ix, 2336. Cholesterin und Lecithin im Wasser- und säure-basenhaushalt. 